\title{
OVERVIEW OF HEALTH BEHAVIORS USING KARO TRADITIONAL MEDICINE IN KARO PEOPLE IN MEDAN CITY
}

\author{
Rosliana Karolina Manalu and Ridhoi Meilona Purba \\ Fakultas Psikologi, Universitas Sumatera Utara \\ rosdliana@gmail.com
}

\begin{abstract}
Keywords: Health Behavior, Karo Community, Traditional Medicine.
Keywords: This research discusses health behaviors in Karo people in Medan. The purpose of this study is to provide an overview of health behaviors using Karo traditional medicine in Karo people in Medan. This research is a descriptive research with a quantitative approach. The method used in data collection is to use a scale of health behavior based on 4 aspects that Notoatmodjo said are promotive, preventive, curative, and rehabilitative with a total of 140 research subjects. The results of this study show health behaviors using Karo traditional medicine are in the moderate category.
\end{abstract}

\section{INTRODUCTION}

Every human being will try to avoid being sick because the condition will cause disruption of various activities and work of a person. Sick people will need healing, while healthy people will need improved health, prevention, repair and health maintenance (Surdarma, 2008).

Based on Law No.36 of 2009, health covers 4 aspects, which means that a person's health is measured not only from physical, mental and social aspects but also by his productivity in the sense of having a job or producing something economically (Notoatmodjo, 2010).

Health behavior can be broadly divided into two broad groups, namely, healthy behavior and illness behavior. Healthy people's behavior to stay healthy is associated with preventive and promotive behaviors to prevent or avoid diseases and causes of diseases/problems and behaviors to improve health.

Meanwhile, the behavior of a sick person or has been affected is related to his or her goal of obtaining healing or solving his health problems. This behavior is called health-seeking behavior. This place of search or health service is a health service facility in the form of traditional health facilities or services or modern or professional medicine such as hospitals, health centers, polyclinics and others (Notoatmodjo, 2010).
The same is the case with Karo people. Karo people also try to avoid illness and need to improve health, prevention, and health improvement like everyone else in general. Data from Bappeda North Sumatra Province states that Karo regency is a regency with the highest life expectancy of 71.99 years. According to the Regional Planning and Development Agency of North Sumatra Province, people's environmental factors and healthy living habits in the Karo Regency caused their life expectancy to be high (Bappeda, 2012).

Karo regency has a geographical location that is highland and strategic to make Karo area fertile. Various types of plants can be planted and growing well and support their community to grow (BPS, 2014). Karo people also use various types of plants as traditional medicines. The use of folk remedies is also part of the culture. Karo people have known various traditional medicines in the past and showed that Karo people know several types of diseases and how to treat them (Tarigan, 1988).

This traditional medicine (both herbal medicine and medicinal plants) is still widely used by the community, especially from the lower middle class. In prevention efforts, healing, recovery of health (rehabilitative), and improvement of health (promotive). Even from the time of the period of traditional medicine undergoes an increasing development, especially with the emergence of the issue back to nature (Katno, 2004).

The definition of traditional medicine according to the Directorate General of Food and Drug Control 
is an ingredient or herb of ingredients in the form of plant ingredients, animal ingredients, mineral ingredients, galenik content or a mixture of such ingredients, which has traditionally been used for treatment based on experience (Notoatmodjo, 2007).

The traditional medicine here is a way of treatment or treatment that is held in other ways outside of medical science or nursing knowledge that is commonly known, refers to knowledge, experience and skills gained through generations, or teachers through education, both native and originating from outside Indonesia, and applied in accordance with the prevailing norms in society (Law No. 23 of 1992 on Health).

Research on traditional medicine in North Sumatra by Syahruddin Lubis in 1995 shows that there is a lot of knowledge about traditional medicine in North Sumatra (Sembiring, 2011). According to Agromedia (2003) the trend of increasing traditional medicine is based on the following reasons (a) the increasingly expensive price of factory-made medicines, so that people begin to receive alternative medicines that are cheap and easy to obtain but no less potent with factorymade medicines, (b) smaller side effects caused by traditional medicines, even certain types of plants show no side effects at all, and (c) the chemical content contained in traditional medicines is actually the basis of modern medicine.

Although modern health services have grown in Indonesia, the number of people choosing traditional medicine remains high. According to the results of the national socioeconomic survey in 2013, the number of traditional medicine users in North Sumatra is about $22.16 \%$ and other treatments are $3.26 \%$. Based on the national socioeconomic survey obtained that the respondent's goal is to use more folk remedies to address complaints of diarrhea, fever, sciatica, headache, cough and colds (Susenas, 2007).

Another factor that affects high life expectancy in Karo Regency with Karo majority of people is the habitual factor of life (Bappeda, 2012).

"Lit Bisa Lit Tawar" is the philosophy of Karo people who have the understanding that every poison must have an antidote and every disease there must be a cure (Ginting, 1999). This is in line with Rospita's assertion (2014) in his research that the basic factors in the form of customs and belief in the results of traditional medicines as well as Karo ethnic views that assume that every disease must have a cure. According to him, this geographical location supports Karo people to make natural resources produced as raw materials in making traditional medicines from time to time (Situmorang, 2014).

The use of traditional medicine is also seen through the results of a survey conducted by researchers to 10 Karo people and each answered still using Karo folk remedies such as burst, param, and Karo oil. Here's the process of saying people who use Karo folk remedies: "If the traditional medicine is still genuine, it is good to make it and from a long time ago it has been used as medicine" (Personal Communication with Mr. Ginting, January 03, 2015).

The use of folk remedies is also used in various age groups, which also use a wide range of Karo folk remedies. Here is one of the speakers of young people who still use traditional Karo medicine: "If Karo oil, still pake. It's all in the house. Because, because it makes the body warm and many benefits. That's why it still makes Karo oil" (Personal Communication, 06 January 2015).

Notoadmodjo (2010) says that basically, healthy behaviors that in this case are associated with the use of folk remedies are influenced by three things namely knowledge, actions and attitudes. In this case, researchers conducted interviews with a couple who worked as Karo traditional medicine. Based on the informant's speech, they gained knowledge of Karo traditional medicine from their former parents. However, until now they are still active in exploring and creating Karo's own folk remedies.

Based on interviews conducted by researchers found that Karo people from various circles still use traditional Karo medicine as a form of their health behavior. Therefore, researchers want to see an overview of health behaviors using traditional Karo medicine in Karo people in Medan.

\section{RESEARCH METHODS}

This research uses descriptive quantitative methods. According to Azwar (2000), descriptive methods aim to systematically and accurately describe facts and characteristics regarding the population or a particular field. The variables used in this study are health behaviors using Karo traditional medicine.

In this study, health behaviors using traditional medicine were measured by the scale of health behaviors that have been created by researchers based on 4 aspects of health behavior according to Notoatmodjo (2010). The first aspect is preventive where the behavior of using traditional medicine is 
carried out before getting sick as an attempt to spread the disease. The second aspect is promotive which is the effort made to improve the health of the individual. The third aspect is the curative aspect as a form of health care search when sick indicated by efforts to use Karo folk remedies to treat individual diseases. The last aspect is the rehabilitative aspect shown by the behavior of the use of Karo traditional medicine in order to recover the condition of the body post-pain.

The population in this study is Karo people domiciled in Medan city with the subject of the study is people with an age category from young adults to seniors domiciled in Medan city. The technique used is incidental sampling with a sample number of 150 people as well as using the scaling of the Likert model.

The validity test used in this study is face validity and content validity, while uji reliability of this measuring instrument uses an internal consistency approach in which the procedure requires only one test imposition to a group of individuals as subjects. The technique used is cronbach's alpha coefficient technique.

The data obtained in this study will be analyzed with statistical analysis intended to answer the formulation of health behavior picture problems using Karo traditional medicine in Karo people in Medan. The data is processed with descriptive analysis and even though this data analysis is done with the help of Spss 22.0 for windows program.

\section{RESULTS AND DISCUSSIONS}

The main results in this study were from 140 Karo people, as many as 74 people or $52.85 \%$ of subjects who belonged to health behavior using moderate Karo traditional medicine, as many as 36 people or $25.7 \%$ were classified in health behavior using low Karo traditional medicine, and the remaining 30 people or about $21.42 \%$ of subjects were classified in health behavior using high Karo traditional medicine.

Based on the data, it can be said that the subject of this study, namely Karo people in Medan city is in the category of using traditional Karo medicine for preventive, promotive, rehabilitative, and curative purposes. The moderate category in some Karo communities means that Karo people still use traditional Karo medicine in addition to the use of modern medicine.

In the preventive aspect there are $55 \%$ of research subjects that are in the moderate category.
In the promotive aspect there are $47.2 \%$ of research subjects who are in the moderate category. In the curative aspect there are $56.5 \%$ that are in the moderate category, and the last in the rehabilitative aspect there is $47 \%$ that is in the moderate category.

Based on the main data of this study shows that Karo people use more traditional Karo medicine in curative order or in other words used to cure diseases in times of illness. Data obtained by researchers in the field, many subjects who say that they tend to forget to use Karo traditional medicine when in good health or do not feel pain, and tend to remember and use Karo folk remedies only when the body already feels pain..

There is a curative aspect, most subjects choose to use Karo oil, param and also burst. Based on the response of the study subjects, it was found that Karo oil is used to cope with sciatica, sores, colds, keram, sprains, hives, coughs, overcoming fatigue, diarrhea, insect stings, toothache, and fractures. Param is widely used to cope with fever, colds, hives, and also headaches. Sembur is a Karo folk remedy consisting of rice, forest leaves, ginger, pepper, nutmeg, and root and others from medicinal plants that are all then chopped not very finely. The way to wear it is to be disbursed to the part of the body that is considered necessary.

In the preventive aspect, based on the results of interviews in the field found that the subject used Karo oil before or after the activity to prevent the appearance of disease. In the promotive health aspect, many research subjects chose to use betel leaf water, param and oukup. While in the rehabilitative aspect, based on the data obtained, most of the study subjects chose to use erpangir, oukup (steam bath) and param as a form of effort to restore post-pain body condition. Erpangir is a type of traditional Karo treatment that is generally done with the aim of removing pesky, relieving fatigue, improving health and relieving stress.

The use of Karo folk remedies in Karo society is inseparable from cultural factors. According to Matsumoto (2004) cultural factors influence a person's way of view in healthy and sick conditions and also affect one's strategy in addressing health problems. Culture also affects the etiology of a disease and also affects how it maintains and improves health (Matsumoto, 2004).

Culture is a response adapted from 3 factors namely ecological factors, social factors and biological factors (Matsumoto, 2004). The first factor is the ecological factor of geographical location, climate, and a number of other natural resources. The geographical location and climate of 
Karo region affects Karo people in terms of their health behavior by utilizing natural resources to be processed into Karo traditional medicine.

The second factor is the social factor. There are several social factors affecting culture including population density, prosperity, technology, types of government, institutions, media, sociocultural and religious hiss. The last factor that influences culture is the biological factor that is a person's temperament and personality (Matsumoto, 2004).

Karo people have a philosophy that states that "Lit can, Lit bargain" which means every poison must have an antidote, or in other words every disease there must be a cure. Karo people have a belief that every disease can be treated, and this philosophy is supported by natural resources in the Karo Land area related to the ecological factors of tanah Karo area used and processed to be used as various types of traditional Karo medicine.

Karo traditional medicine culture based on the philosophy of "lit bisa lit tawar" will experience an enculture process that then produces the culture as it is today. Enculture is the process by which a person learns and adopts the ordinances, rules and practices of their culture (Matsumoto, 2004). According to Matsumoto (2004) parents and families play an important role in the enculture and socialization process. In addition to parents and families, there are other agents that can influence the process of enculture such as siblings, peers, social groups and so on.

That's how a culture can influence a person's behavior. Similarly, Karo people in Medan who still use traditional Karo medicine as a form of health behavior, are not separated from the influence of a culture transferred from the previous generation to the current generation. There is a family role in related health behaviors in this case related to the selection of Karo traditional medicine use. Based on data obtained that $45 \%$ of parents play a role in providing information about the use of Karo folk remedies as a form of health behavior.

\section{REFERENCES}

Katno, P. S., 2004. Tingkat Manfaat dan Keamanan Tanaman Obat dan Obat, yogyakarta: Fakultas Farmasi UGM.

Matsumoto, D., and Linda J. (2004). Culture and psychology. Wadsworth/Thomson Learning 10 Davis Drive Belmont, CA 94002-3098, USA.

Moore, R., Lopes, J., 1999. Paper templates. In TEMPLATE'06, 1st International Conference on Template Production. SCITEPRESS.

Notoatmodjo S. 2010. Ilmu Perilaku Kesehatan. Jakarta: PT Rineka Cipta

Notoatmodjo, S. 2007. Promosi Kesehatan dan Ilmu Perilaku. Jakarta : Rineka Cipta

Situmorang RO, Alfonsus HH. Faktor-faktor yang mempengaruhi kearifan lokal pemanfaatan obatobatan tradisional oleh Etnik Karo. 2014.

Saifuddin Azwar, 2000. Metode Penelitian, Pustaka Pelajar Offset, Yogyakarta

Smith, J., 1998. The book, The publishing company. London, $2^{\text {nd }}$ edition.

Suryadarma, 2008. Etnobotani. Diktat Kuliah Jurusan Pendidikan Biologi MIPA : Universitas Negeri Yogyakarta. 